Swarthmore College

Works

$9-1-2010$

\title{
Bioluminescent Escherichia Coli Strains For The Quantitative Detection Of Phosphate And Ammonia In Coastal And Suburban Watersheds
}

Cristina V. Cardemil , '01

D. R. Smulski

R. A. LaRossa

Amy Cheng Vollmer

Swarthmore College, avollme1@swarthmore.edu

Follow this and additional works at: https://works.swarthmore.edu/fac-biology

Part of the Biology Commons, and the Microbiology Commons

Let us know how access to these works benefits you

\section{Recommended Citation}

Cristina V. Cardemil , '01; D. R. Smulski; R. A. LaRossa; and Amy Cheng Vollmer. (2010). "Bioluminescent Escherichia Coli Strains For The Quantitative Detection Of Phosphate And Ammonia In Coastal And Suburban Watersheds". DNA And Cell Biology. Volume 29, Issue 9. 519-531. DOI: 10.1089/dna.2009.0984 https://works.swarthmore.edu/fac-biology/17

This work is brought to you for free by Swarthmore College Libraries' Works. It has been accepted for inclusion in Biology Faculty Works by an authorized administrator of Works. For more information, please contact myworks@swarthmore.edu. 


\title{
Bioluminescent Escherichia coli Strains for the Quantitative Detection of Phosphate and Ammonia in Coastal and Suburban Watersheds
}

\author{
Cristina V. Cardemil, ${ }^{1, \star}$ Dana R. Smulski, ${ }^{2}$ Robert A. LaRossa, ${ }^{2}$ and Amy Cheng Vollmer ${ }^{1}$
}

Accumulation of phosphate and ammonia in estuarine systems and subsequent dinoflagellate and algal blooms has been implicated in fish kills and in health risks for fishermen. Analytic chemistry kits are used to measure phosphate and ammonia levels in water samples, but their sensitivity is limited due to specificity for inorganic forms of these moieties. An Escherichia coli bioluminescent reporter system measured the bioavailability of inorganic nutrients through fusion of E. coli promoters ( $p h o A$ or $g \ln A p 2$ ) to the luxCDABE operon of Vibrio fischeri carried either on the chromosome or on a multicopy plasmid vector, resulting in emission of light in response to phosphate or ammonia starvation. Responses were shown to be under the control of expected physiological regulators, $p h o B$ and $g \ln F G$, respectively. Standard curves were used to determine the phosphate and ammonia levels in water samples from diverse watersheds located in the northeastern United States. Bioluminescence produced in response to nutrient starvation correlated with concentrations of phosphate (1-24 ppm) and ammonia (0.1-1.6 ppm). While the ammonia biosensor measured nutrient concentrations in tested water samples that were comparable to the amounts reported by a commercial kit, the phosphate biosensor reported higher levels of phosphate in Chesapeake water samples than did the kit.

\section{Introduction}

E SCHERICHIA COLI QUICKL $Y$ RESPONDS to a wide range of stressors in a variety of ways that include chemotactic responses (Macnab, 1987) and adjustments of metabolic flux (LaPorte et al., 1985). Other adaptations result from changes in gene expression that can be monitored after the in vivo (Casadaban and Cohen, 1979) or in vitro (Casadaban and Cohen, 1980) construction of promoter fusions to easily assayable structural genes such as lacZ, galK, cat, lux $A B$, and luxCDABE (Miller, 1992). Strategies have used such fusions to define the breadth of responses to a given damage (Kenyon and Walker, 1980) and to monitor the damage itself (Quillardet et al., 1982). Many damage-inducible promoters have been fused to the $\operatorname{lu} x \mathrm{CDABE}$ genes of Vibrio fischeri: katG (Belkin et al., 1996); grpE and dnaK (Van Dyk et al., 1994, 1995a); recA, uvrA, and alkA (Vollmer et al., 1997); uspA (Van Dyk et al., 1995b) fusions are useful for the detection and typing of stress due to oxidation, heat shock, genotoxicants, and number of stresses, respectively. This induction of gene expression in such fusions is indicated by in vivo bioluminescent increases, which can be conveniently quantitated in a near-continuous, nondestructive manner using microtiter plate format luminometry (Belkin et al., 1994; Belkin et al., 1997; LaRossa and Van Dyk, 2000). Expression of the five lux polypeptides in E. coli produces a visual and quantifiable phenotype, namely, light emission (Engebrecht, 1984). The advantage of including luxCDE as well as the luxAB-encoded luciferase is that the needed substrates are shunted from fatty acid biosynthesis, converted to fatty aldehydes. Additionally, the reactions require reduced flavin mononucleotide (FMN) as well as oxygen. Depletion of the fatty acid pools or redox carriers has the consequence of decreased light production. The use of bacteria as environmental biosensors has been recently reviewed (Belkin, 2003; Vollmer and Van Dyk, 2004).

Several global regulatory circuits monitor other aspects of cellular health such as metabolic integrity (Neidhardt et al., 1990). These metabolic responses could also be useful indicators of deliberate or accidental stresses placed upon the environment (Paerl, 1993). In the past three decades coastal zones and estuaries, among the most productive ecosystems on the Earth (Rayl, 2000), have seen major changes in these areas due to nutrient accumulation. Eutrophication of bays and estuaries by human industry and settlement contributes to this increase of nutrients, which are biologically useful forms of phosphorus and nitrogen (National Research Council, 2000). Phosphorus and nitrogen enrichment can beneficially affect primary productivity (Richardson and Jorgensen, 1996; Nixon, 1988); however, abnormally high

\footnotetext{
${ }^{1}$ Department of Biology, Swarthmore College, Swarthmore, Pennsylvania.

${ }^{2}$ Central Research and Development, DuPont Company, Wilmington, Delaware.

${ }^{*}$ Current affiliation: Children's National Medical Center, NW Washington, D.C.
} 
increases in nutrient concentrations have detrimental effects. While bacterial and algal growth is stimulated by abnormally high levels of nitrogen and phosphorus changes in the ecosystems, decreased water clarity and oxygen deficits (hypoxia and anoxia) result, causing habitat loss, food chain disruptions, eutrophication, and threats to biodiversity. The threat of eutrophication today is found along the edges of all continents except Antarctica (Richardson and Jorgensen, 1996; Mallin, 2000; National Research Council, 2000). One region of concern is the Chesapeake Bay, the largest estuary in North America. This ecosystem has been subject to anoxic conditions and eutrophication since European settlement (Cooper and Brush, 1991). In the last two decades, the Chesapeake Bay has been adversely affected by additional phosphorus and nitrogen inputs. Algal and microbial blooms have repeatedly occurred exemplified by, but not limited to, the toxic and persistent dinoflagellate Pfiesteria piscicida (Mallin, 2000), and anoxia in the deeper portions of the Chesapeake Bay have been observed (Officer et al., 1984).

To prevent the detrimental health and ecological impacts of pathogens such as Pfiesteria on aquatic and terrestrial organisms, environmental monitoring of nutrient concentrations in water systems is essential. By measuring phosphate and ammonia concentrations at periodic intervals, the sources of nutrient upswings can be traced. (We use the term "ammonia" to represent biologically usable forms of nitrogen.) Chemical kits exist to measure phosphate and ammonia levels in water, but their dynamic range and ability to detect bioavailable sources of these compounds are limited, due to reliance on inorganic ammonia or phosphate complex formation and spectrophotometric detection of chromogenic substrates. Thus, it would be extremely useful to develop a more sensitive system to accurately assess the change in bioavailable nutrients.

When phosphate and ammonia (or other biologically useful amine-containing compounds) are found in limited quantities, cells respond greatly elevating the high affinity binding and transport of these nutrients from the environment (Neidhardt, 2000). While there have been previous studies detecting ammonia and phosphate levels by promoter::lux fusions using fresh cultures of cyanobacteria for water samples (Gillor et al., 2002, 2003) and Pseudomonas fluorescens for soil nutrient measurements (Koch et al., 2001; Standing et al., 2003), this investigation uses cells that have been cultured and stored so that the lag in response time is diminished. Freshly cultured bacteria display a prolonged lag time as they scavenge all internal sources of phosphate and/or ammonia before activating $p h o A$ and/or $g \ln A$, respectively. (The responses of E. coli promoter-lux fusions to nutritional deficiencies have been characterized in preliminary laboratory studies.) (Smulski et al., 1994, 1996). A protocol is presented for testing nutrient concentrations using the $p h o A^{\prime}:: l u x$ and $g \ln A^{\prime}:: l u x$ bioluminescent strains, as it was used on the collected water samples, based on standard curves of luminescence that report nutrient levels within a calibration interval of $95 \%$ confidence.

\section{Materials and Methods}

\section{Bacterial strains and plasmids}

Strain construction and promoter cloning. Oligonucleotides, E. coli strains, and plasmids (and their sources) used in this study are listed in Table 1. The oligonucleotides (synthesized at the DuPont Macromolecular Analysis Facility) were designed to allow directional ligation of the polymerase chain reaction (PCR) product to the pUCD615 (Rogowsky et al., $1987)$ vector EcoRI and Bam HI restriction sites digestion as described previously (Van Dyk et al., 1994). Promoter regions were amplified using the PCR using the following primers (which include restriction endonuclease recognition regions)—for phoA: $5^{\prime}$ ACTTAAGGATCCAGATTATCGTCA CTGCAA $3^{\prime}$ (italicized bases, preceded by a BamHI recognition site, are -232 to -215 , with respect to transcription start) (Kikuchi et al., 1981) and 5' AGCAGCGAATTCGGCCAAT CAGCAAAATAA $3^{\prime}$ [italicized bases, preceded by an EcoRI recognition site, are +241 to +257 , with respect to transcription start, as identified by Makino et al. (1986)]; for $g \ln A p 2: 5^{\prime}$ ACTTTCGGATCCTTGGTGCAACATTCACAT $3^{\prime}$ (italicized bases, preceded by a Bam $\mathrm{HI}$ recognition site, are -128 to -111 , with respect to transcription start) and $5^{\prime}$ AGCAGCGAA TTCTCAGCGGACATACTTAAC 3' (italicized bases, preceded by an $E c o$ RI recognition site, are +65 to +82 , with respect to transcription start). The regulatory region cloned from the $g \ln A$ upstream region contained only the promoter element that is responsive to nitrogen starvation $(g \ln A p 2$ and not $g \ln A p 1)$ (Reitzer and Magasanik, 1985). The template for the amplification of the promoters was genomic DNA from $E$. coli strain W3110. Plasmid DNA was isolated (Qiagen) and, following ligation, transformed, initially into a DH5 recipient for propagation (Davis et al., 1980) and subsequently of global regulatory mutants or strains W3110 and RFM443 generally used for initial bioluminescent characterization (see Table 1 for strain listings and sources). Kanamycin resistance was used to select for transformants in all cases. Single-copy integrants of $p h o A^{\prime}:: \operatorname{lu} x C D A B E$ and $g \ln A p 2^{\prime}$ : :luxCDABE were created as described previously (Elsemore, 1998).

Verification of fusion structures. The genomic structures of the fusions were verified as previously described (Van Dyk et al., 1995b, Belkin et al., 1996). The size of the fusions was estimated by agarose gel electrophoresis of the PCR product delineated by the upstream termini of the promoter segment and a sequence present in luxI, as previously described (LaRossa et al., 1995). Full verification of cloned promoters was confirmed by DNA sequencing (Vollmer, data not shown).

\section{Bacterial cell preparation, storage, and viability}

Growth media. Heavy metal MOPS (HMM) minimal medium was used for phosphate limitation experiments (LaRossa et al., 1995). Complete $1 \times \mathrm{HMM}$ medium contained $40 \mathrm{mM}$ MOPS, $50 \mathrm{mM} \mathrm{KCl}, 10 \mathrm{mM} \mathrm{NH}_{4} \mathrm{Cl}, 0.5 \mathrm{mM} \mathrm{MgSO}_{4}$, $0.02 \mu \mathrm{M} \mathrm{FeCl}_{3}, 0.4 \%$ glucose, $0.025 \%$ uridine, and $0.00005 \%$ thiamine (LaRossa et al., 1995). A low concentration of glycerol phosphate $(5 \mathrm{mM})$ was supplied as the poor phosphate source, such that the viability of the cells was maintained without compromising the pho $A$ induction. Inorganic phosphate was added in the form of potassium phosphate ( $\mathrm{pH}$ 7.0). Bender's minimal medium (BMM) was used for ammonia starvation experiments (Bender et al., 1977). About $1 \times \mathrm{BMM}$ consisted of $120 \mathrm{mM} \mathrm{K} \mathrm{HPO}_{4}, 66 \mathrm{mM} \mathrm{KH}_{2} \mathrm{PO}_{4}$, $0.02 \% \mathrm{MgSO}_{4}, 3.4 \mathrm{mM}$ sodium citrate, $0.2 \%$ glucose, and $0.005 \%$ thiamine. A low concentration of glutamine $(0.04 \%)$ 
Table 1. Plasmids and Escherichia coli Strains

\begin{tabular}{|c|c|c|}
\hline Plasmids & Description and/or source & Reference \\
\hline pUCD615 & Plasmid with promoterless luxCDABE operon & Rogowsky et al. (1987) \\
\hline pGlnALux3 & $\begin{array}{l}\text { Contains nucleotides } 144-334 \text { of the Escherichia coli } \\
\text { glnALG operon: } g \ln A \text { gene coding for glutamine synthetase, } \\
\text { promoter region-denoted in GenBank accession number } \\
\text { M10421 inserted into pUCD615 between BamHI and EcoRI sites }\end{array}$ & This work \\
\hline pPhoALux5 & $\begin{array}{l}\text { Contains nucleotides } 10-498 \text { of the E. coli alkaline } \\
\text { phosphatase (phoA) gene, } 5^{\prime} \text { end denoted in GenBank } \\
\text { accession number M33536 inserted into pUCD615 } \\
\text { between BamHI and EcoRI sites }\end{array}$ & This work \\
\hline General strains & Genotype & Reference \\
\hline DH5 & 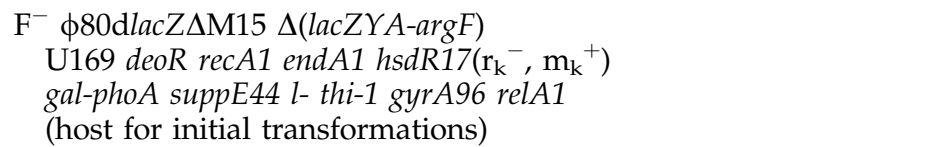 & Hanahan (1983) \\
\hline RFM443 & galK2 lac74 rpsL200 & Menzel (1989) \\
\hline W3110 & $\mathrm{F}^{-}$ & $\begin{array}{l}\text { Bachmann (1996), } \\
\text { Ernsting et al. (1992) }\end{array}$ \\
\hline BW13711 & phoB $^{+} \Delta($ lacIZYA) X74 & Metcalf et al. (1990) \\
\hline BW14087 & BW13711 phoB23 & Metcalf et al. (1990) \\
\hline YMC10 & $\begin{array}{l}g \ln G^{+} g \ln F^{+} \text {endA thi-1 hsdR17 supE44 } \\
\text { DlacU169 hutC }{ }^{+}(\text {Klebsiella })\end{array}$ & Chen et al. (1982) \\
\hline YMC17 & YMC10 $g \ln G:: \operatorname{Tn} 5$ & Chen et al. (1982) \\
\hline TH1 & YMC10 glnF::Tn10 & Chen et al. (1982) \\
\hline DPD1524 & pPhoALux5 in W3110 & This work \\
\hline DPD1528 & pPhoALux 5 in RFM443 & This work \\
\hline DPD1704 & pPhoALux5 in BW13711 & This work \\
\hline DPD1705 & pPhoALux5 in BW14087 & This work \\
\hline DPD2828 & pGlnALux3 in W3110 & This work \\
\hline DPD2832 & pGlnALux3 in RFM443 & This work \\
\hline DPD1699 & pGlnALux3 in YMC10 & This work \\
\hline DPD1700 & pGlnALux3 in YMC17 & This work \\
\hline DPD1701 & pGlnALux3 in TH1 & This work \\
\hline
\end{tabular}

was added to the medium. This allowed for growth of the cells and did not interfere with the induction of $g \ln A$. Ammonia was supplied in the form of $\left(\mathrm{NH}_{4}\right)_{2} \mathrm{SO}_{4}$.

Preparation of frozen cells. Single-colony isolates of each strain were cultured in $5 \mathrm{~mL}$ Luria-Bertani containing $25 \mu \mathrm{g} / \mathrm{L}$ kanamycin with aeration for $24 \mathrm{~h}$ at $37^{\circ} \mathrm{C}$, and subsequently transferred to a $200 \mathrm{~mL}$ culture containing the same medium. Cells were then rapidly pelleted by centrifugation and washed twice in $1 \times$ HMM or $1 \times$ BMM, and resuspended in half the culture volume in $2 \times \mathrm{HMM}$ or $2 \times$ $\mathrm{BMM}$ and $35 \%$ glycerol. Cells were stored as frozen aliquots at $-20^{\circ} \mathrm{C}$, and thawed to room temperature before use. The viability of frozen stock cells was assessed each month. Cells were serially diluted 10 -fold in $0.8 \% \mathrm{NaCl}$, plated on LuriaBertani agar with $25 \mu \mathrm{g} / \mathrm{L}$ kanamycin, and incubated at $37^{\circ} \mathrm{C}$ overnight, and colony-forming units were enumerated subsequently. Similarly, viability of cells in the duration of each luminometer assay was measured at the beginning, end, and at a few middle time points by serially dilution and plating. (The luminometer did not have the capability of spectrophotometric measurements of OD at 600.)

Bioluminescent techniques. Several of these techniques such as detection of bioluminescent transformants by expo- sure of X-ray film to Petri dishes and near-continuous measurement of bioluminescence with a microtiter plate luminometer in black opaque microtiter plates have been detailed in a previous communication (Van Dyk et al., 1994).

\section{Creating and using standard curves}

For phosphate limitation, $2 \times \mathrm{HMM}$ with $0.5 \mathrm{mM}$ potassium phosphate was serially diluted in $1 \times$ HMM to a final volume of $50 \mu \mathrm{L}$ in each well of a 96-well opaque black microtiter plate, in duplicate rows of wells. The same procedure was followed for ammonia limitation using $2 \times \mathrm{BMM}$ with $30.4 \mathrm{mM}\left(\mathrm{NH}_{4}\right)_{2} \mathrm{SO}_{4}$. Fifty microliters of E. coli $p h o A^{\prime}:: l u x$ and $g \ln A^{\prime}:: \operatorname{lux}$ cells, as prepared above, was thawed at room temperature and added to each well. The microplate was then read every $30 \mathrm{~min}$ in the Topcount luminometer (Packard) for $30 \mathrm{~h}$ at $25^{\circ} \mathrm{C}$ to determine bioluminescence (relative light units [RLU]) as a function of time.

Next, bioluminescent values from the kinetic curves were then taken at the same time point during the most responsive portion of the curve, at all nutrient concentrations. A standard curve of luminescence was created as a function of nutrient concentration. Phosphate and ammonia concentrations of unknown titers were interpolated within a calibration interval, defined to be the linear portion of the curve. Intervals of nutrient concentrations with $95 \%$ confidence 
were predicted. The calibration intervals were calculated using the standard error of prediction (Ramsey and Schafer, 1997). Nutrient concentrations that fell below and above the linear portion of the standard curve were not included (see Appendix for additional statistical calculations.)

\section{Water sample collection and testing}

Water was collected from the edge of rivers and waterways in $50 \mathrm{~mL}$ Falcon tubes, transported to the lab, and filtered via a $0.22 \mu \mathrm{m}$ Millipore Express filter. Standard curves were created each time a sample was tested, and used to test nutrient levels in water samples. In a microplate, water samples were serially diluted 10 -fold in $2 \times \mathrm{HMM}$ or $2 \times \mathrm{BMM}$ to a final concentration of $1 \times \mathrm{HMM}$ or $1 \times \mathrm{BMM}$, in duplicate rows of wells. E. coli pho $A^{\prime}:: \operatorname{lux}$ and $g \ln A^{\prime}:: \operatorname{lux}$ cells were added, and bioluminescence read in the Topcount luminometer as described above. Bioluminescence for the water samples was recorded at the same time point used to graph the standard curve. Bioluminescent values were then substituted into the equations for the calibration intervals on the standard curve to determine the lower and upper bounds of nutrient concentration. For each experiment testing water samples of unknown concentrations, one previously tested water sample was included and served as an internal standard.

\section{Comparison with known standards and commercial kits}

The standard curves created by the biological sensors were tested for accuracy by using water samples with known nutrient concentrations. Such standards were created by diluting measured concentrations of ammonia and phosphate in distilled water and added to the bacterial samples such that the overall $\mathrm{pH}$ was not changed. Standard curves were created as above, water samples of known inorganic phosphate and ammonia concentrations were incubated in the luminometer with the strains, bioluminescence was recorded at the same peak time point as the standard curve, and nutrient concentrations were calculated according to the standard curves. In addition, water samples were tested for phosphate concentrations (orthophosphates) using LaMotte model VM-12 phosphate test kit (code 4408) and ammonia concentrations using LaMotte ammonia-nitrogen test kit (code 5864) as per manufacturer's instructions, and compared to the nutrient concentrations reported by the biological sensors. Finally, the chemical kits were tested against water samples of known inorganic phosphate and ammonia concentrations.

\section{Results}

pho $A^{\prime}::$ luxCDABE induction by phosphate limitation

Preliminary data (Smulski et al., 1996) indicated that phosphate concentrations ranging from 30 to $2000 \mu \mathrm{M}$ repressed specific light emission, apparently due to prevention of transcription initiation at the phoA promoter. Figure $1 \mathrm{~A}$ shows the kinetic response of the $p h o A^{\prime}:: l u x$ fusion to limiting phosphate concentrations, between 0 and $30 \mu \mathrm{M}$. While weak level light expression was maintained by $30 \mu \mathrm{M}$ phosphate, lower concentrations resulted in increased production. After a lag of over $200 \mathrm{~min}$, bioluminescence increased $>1000$-fold over the level seen when a parallel culture was resuspended in high phosphate medium. The highest concentration that elicited a starvation response was $15 \mu \mathrm{M}$ phosphate. The lowest concentration that yielded a response that was distinguishable from totally starved (no phosphate) growth conditions was $1.8 \mu \mathrm{M}$. A direct correlation between induction time and initial phosphate concentration is apparent. That is, increasing amounts of exogenous phosphate resulted in greater delays in the time at which increased luminescence was detected. This correlation is shown in another way in Figure 2: the time at which each kinetic curve intersects 10 RLU. There is no correlation between the peak height (amplitude) of the response and the concentration of phosphate. Further, peak height does not correlate with the severity of limitation.
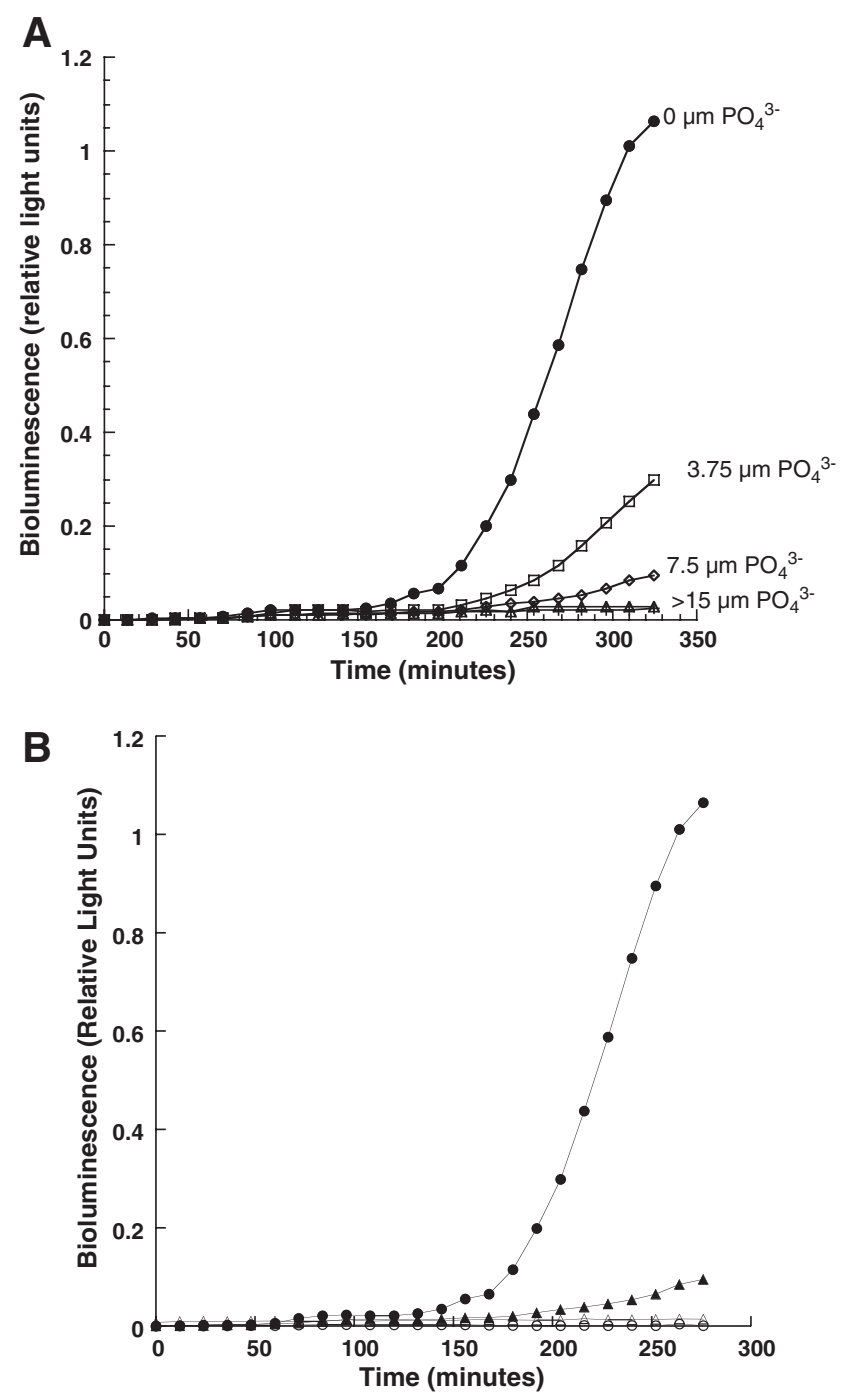

FIG. 1. (A) Shown is the kinetic response of the DPD1524 to decreasing phosphate concentrations 30, 15, 7.5, 3.75, and $0 \mu \mathrm{M}$. (B) Comparison of the response of $p h o A^{\prime}:: l u x C D A B E$ biosensor to decreasing levels of phosphate in wild-type (DPD1704; solid symbols) and phoB-backgrounds (DPD1705; open symbols); circle, no phosphate; triangle, $3.75 \mu \mathrm{M}$. 


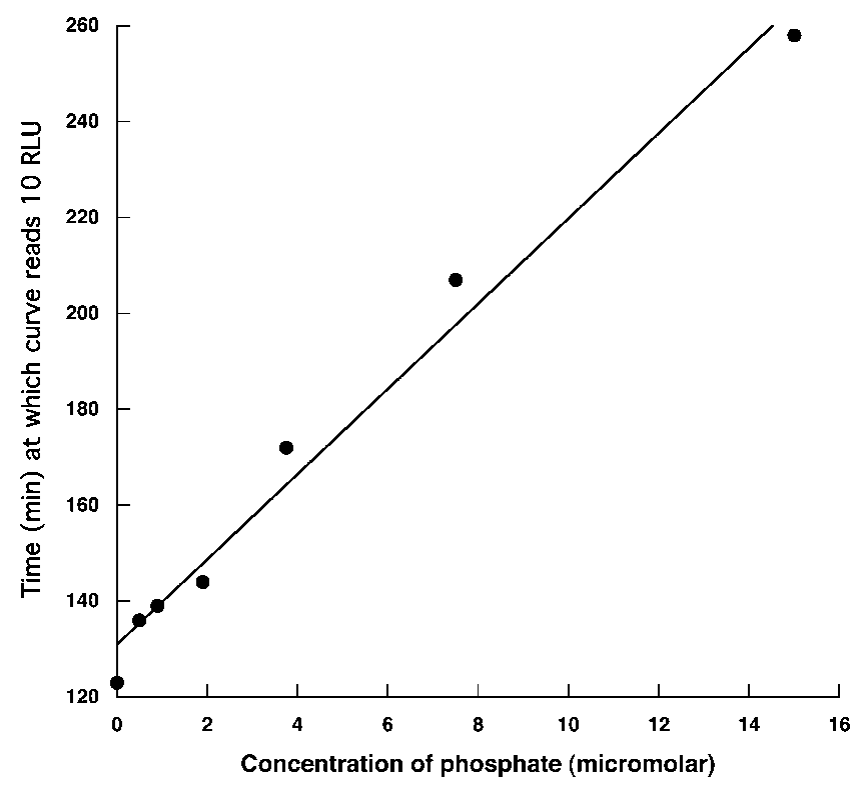

FIG. 2. Correlation between concentrations of phosphate and time at which kinetic curves reach the level of 10 relative light units (RLU). Equation for the line $y=1.3 e+02+8.9 x$; $R=0.99$. If $15 \mu \mathrm{M}$ sample is left out, the equation becomes $y=1.3 \mathrm{e}+2+11 x ; R=0.99$.

\section{Dependence of phoA induction on pho regulatory genes}

It is expected that transcriptional regulation of this fusion would be controlled by the pho regulon (Wanner, 1987). The phoB gene product is activated when the external inorganic phosphate concentration is low. In its activated form it stimulates transcription of the pho regulon genes, including pho $A$, which encodes a periplasmic alkaline phosphatase. Figure $1 \mathrm{~B}$ shows that light emission from $p h o A^{\prime}:: \operatorname{lux} C D A B E$ was dependent on $p h o B$ function.

\section{glnAp2'::luxCDABE induction by nitrogen limitation}

The $g \ln A p 2^{\prime}:: \operatorname{lux}$ fusion was constructed as a tool to detect stress in response to nitrogen limitation. The $g \ln A$ gene is part of the $g \ln A L G$ operon, which codes for the nitrogenregulated (NTR) proteins, namely, glutamine synthetase (GS), nitrogen regulator II (NRII), and nitrogen regulator I (NRI). Nitrogen limitation induces the synthesis of GS, the primary enzyme of ammonia assimilation (Magasanik and Neidhardt, 1987; Reitzer and Magasanik, 1987). The reaction catalyzed by GS, converting glutamate to glutamine, is key because the latter is the sole nitrogen source for the synthesis of amino acids, proteins, purines, and pyrimidines. The levels of glutamine/glutamate/ $\alpha$-ketoglutarate serve to maintain a ready level of ammonia buffered to physiological conditions. To test the inducibility of the fusions, the cells (DPD1635) were subjected to a medium that was limiting for or devoid of any inorganic source of ammonia. The test medium included glutamine $(0.27 \mu \mathrm{M})$ so that there would be some nitrogen available for the synthesis of the proteins necessary for bioluminescence. As this nitrogen reserve became depleted, the $g \ln$ (NTR) regulon would be activated. As shown in Figure 3A, cells grown in the absence of ammonia exhibited the greatest increase in luminescence, which was 170 -fold over that of the uninduced control cells. The second greatest induction response was elicited by the cells grown in the absence of ammonia, but in the presence of $0.24 \mu \mathrm{M}$ glutamine. Concentrations $>0.48 \mu \mathrm{M}$ ammonia did not show any increase in light production, mimicking the basal light emission of the uninduced cells grown in high concentrations of ammonia. As the concentration of ammonia increased, the amplitude of the light response decreased, and more time was required before observing the induction. Therefore, the degree of starvation correlates with the peak height and induction time. The lowest detectable concentration tested that elicited a response that was distinguishable from the no ammonia control was $0.038 \mathrm{nM}$ ammonia (Smulski et al., 1996).
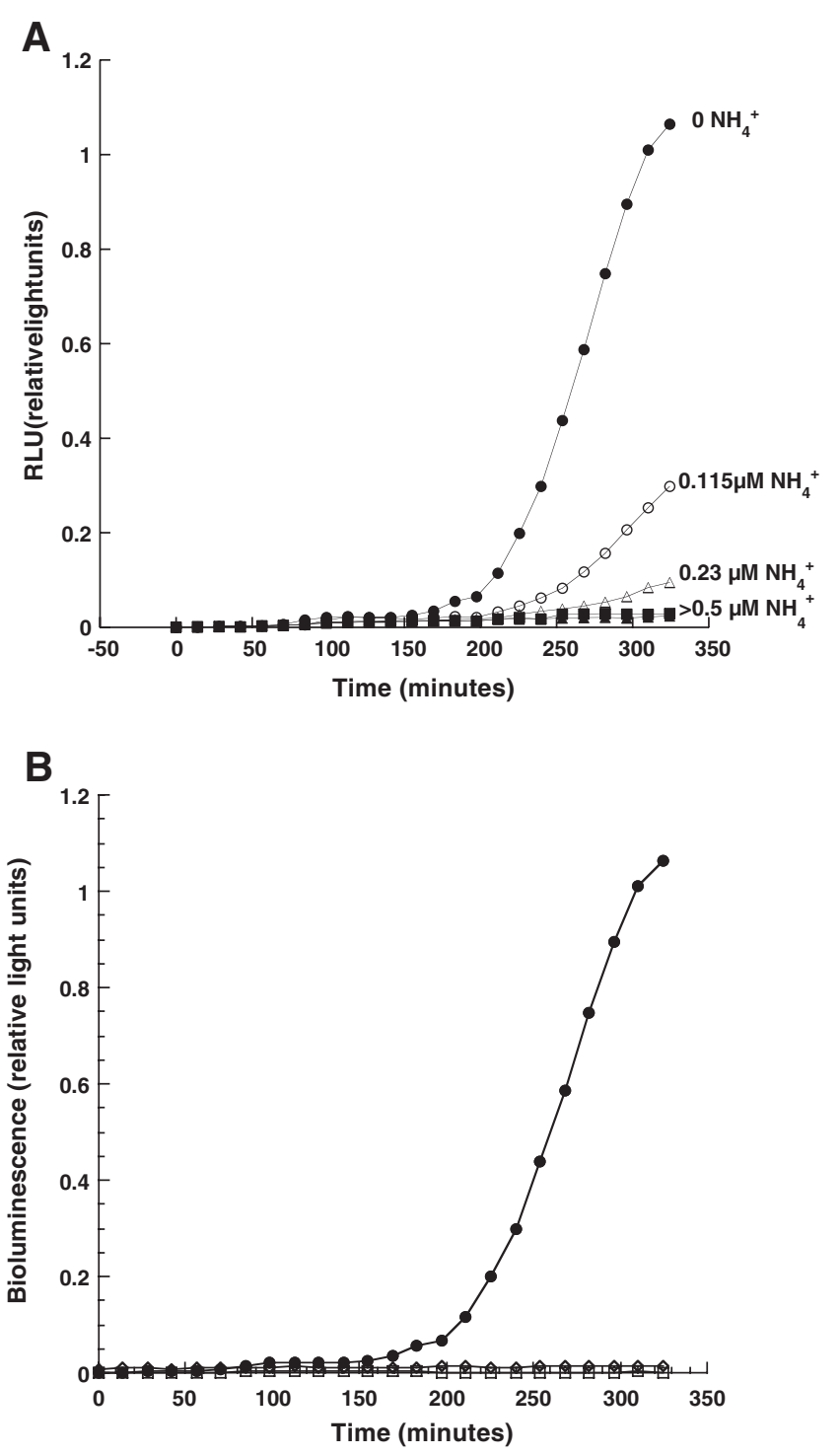

FIG. 3. (A) Shown is the kinetic response of the DPD2828 to decreasing ammonia concentrations $3.8,0.48,0.24,0.12$, and $0 \mu \mathrm{M} ; 1.9$ and $0.96 \mu \mathrm{M}$ data were omitted for clarity. (B) Comparison of the response of the $g \ln A p 2^{\prime}:: \operatorname{lu} x C D A B E$ biosensor to ammonia starvation in wild type (DPD1699; solid circles), $g \ln F^{-}$(DPD1700; open diamonds), and $g \ln G^{-}$ (DPD1701; open squares). 


\section{Dependence of glnA induction on gln regulatory genes}

Physiological control of the nitrogen regulon is very complex, involving many regulators and effectors that control the activity and synthesis of GS. Since the nitrogenlimiting biosensor relies solely on the initiation of transcription of the $g \ln A p 2$ promoter, we were only concerned with the subset of the regulon's regulatory machinery involved in $g \ln A p 2$ control. The $g \ln A$ induction occurs in response to depletion of nitrogen from the medium. Transcription from $g \ln A p 2$ requires the phosphorylated form of NRI and RNA polymerase complexed with the minor factor, sigma 54 . The $g \ln G(n t r C)$ and the $g \ln F(r p o N$ and $n t r A)$ genes encode the NRI and the sigma 54 proteins, respectively (Magasanik and Neidhardt, 1987; Reitzer and Magasanik, 1987). Figure 3B shows that host cells (DPD1700 and DPD1701) mutated in these two genes were not able to respond to nitrogen starvation growth conditions. Instead, they exhibited a light response that was indistinguishable from wild-type cells grown in a high-ammonium medium.

\section{Use of the promoter::Iux fusions} as environmental biosensors

Table 2 showed the lag time in the response of $p h o A$ from exponentially growing cells. With higher concentrations of phosphate, the lag times also increased. Kinetic curves showed the lag times in bioluminescence of samples of known phosphate or ammonia concentration over a period of $20 \mathrm{~h}$. The response is dose dependent for phosphate starvation (Fig. 1A) as well as ammonia starvation (Fig. 3A); that is, the biosensors respond to increasing nutrient starvation with increasing amounts of light. Each of the kinetic graphs shown is representative of the kinetic curves created for each experiment that tested water samples (five independent experiments for phosphate and four for ammonia).

Standard curves show bioluminescence (log of RLU) as a function of nutrient concentration at a time point of peak or increasing luminescence (in these graphs, at $14 \mathrm{~h}$ for phosphate and $10.9 \mathrm{~h}$ for ammonia limitation), taken from the kinetic curves. A linear response is observed in response to phosphate limitation, reporting values in between 0.4 and $15.8 \mathrm{ppm}$ (Fig. 4), and in response to ammonia limitation, reporting values between 0.2 and 1.5 ppm (Fig. 5). Each depicted standard curve shown is representative of the standard curves created for each experiment. Most standard curves were created between 1 and $24 \mathrm{ppm}$ phosphate, and 0.6 and $1.6 \mathrm{ppm}$ ammonia. Calibration intervals indicate with $95 \%$ confidence a range of nutrient values when given a

Table 2. Phosphate Concentration and Delay OF PHOA::LUX INDUCTION

\begin{tabular}{lc}
\hline$\left[\mathrm{PO}_{4}\right]^{3-} n M$ & Induction time (min) \\
\hline 0 & 210 \\
470 & 211 \\
940 & 222 \\
1870 & 231 \\
3750 & 254 \\
7500 & 288 \\
15,000 & 335 \\
30,000 & 384 \\
\hline
\end{tabular}

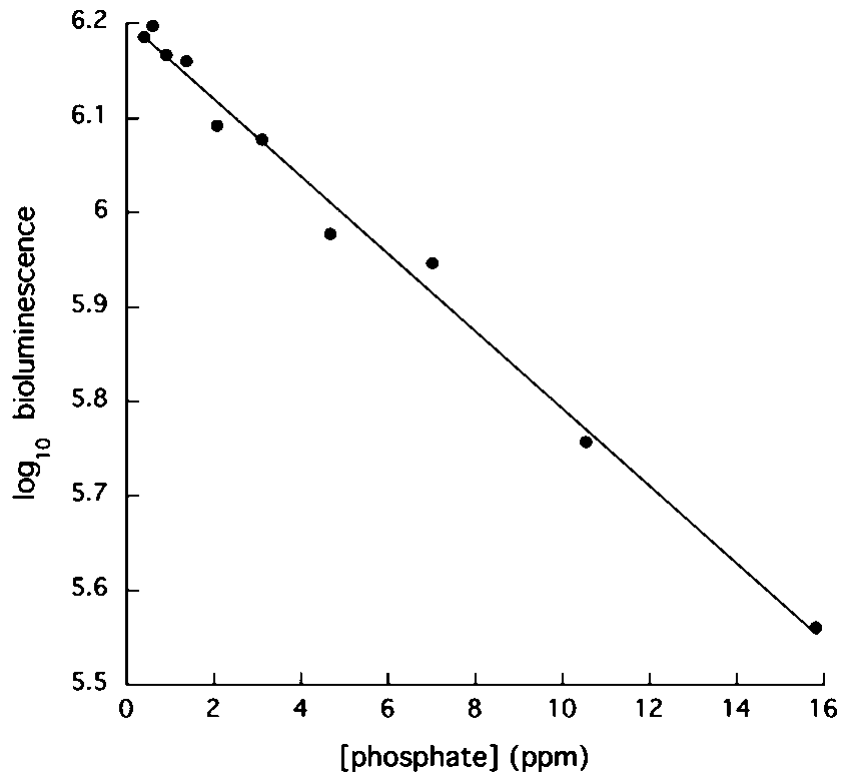

FIG. 4. Dose-response curve of DPD1524. Time points were taken at $14.5 \mathrm{~h}$ of incubation. The equation for the line shown is $y=6.202-0.041 x$. The equations for the lines indicating $95 \%$ confidence range: lower limit, $y=6.243-0.041 x$; upper limit, $y=6.162-0.041 x$.

sample of known bioluminescence. These values were calculated for each water sample collected and tested to report nutrient concentrations (Tables 3 and 4).

To assess the accuracy of the biological sensor, and to be able to compare water sample nutrient values reported by the biosensor to the LaMotte kits, both systems were tested with water samples of known inorganic phosphate and ammonia concentrations, and the results were compared.

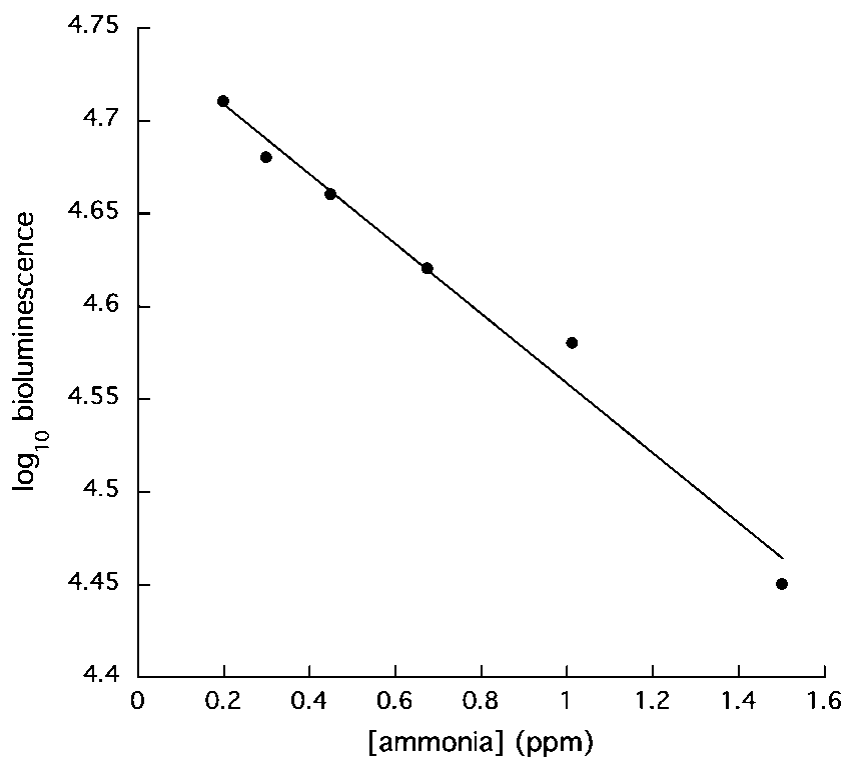

FIG. 5. Dose-response curve of DPD2828. Time points were taken at $14.7 \mathrm{~h}$ of incubation. The equation for the line shown is $y=4.746-0.188 x$. The equations for the lines indicating $95 \%$ confidence range: lower limit, $y=4.778-0.183 x$; upper limit, $y=4.713-0.189 x$. 
Table 3. Comparison of Calculated Phosphate Concentrations to KnOWn Concentrations of Phosphate in Water

\begin{tabular}{lc}
\hline Determined $\left[\mathrm{PO}_{4}{ }^{3-}\right](\mathrm{ppm})$ & $\begin{array}{c}95 \% \text { Confidence } \\
\text { interval }(p p m)\end{array}$ \\
\hline 15.83 & $14.46,18.82$ \\
10.56 & $9.38,14.65$ \\
7.04 & $5.58,7.71$ \\
4.69 & $3.40,5.49$ \\
3.13 & $1.52,3.57$ \\
2.09 & $0.48,2.50$ \\
1.39 & $0.00^{\mathrm{a}}, 1.33$ \\
0.93 & $0.00^{\mathrm{a}}, 1.10$ \\
0.62 & $0.00^{\mathrm{a}}, 0.92$ \\
0.41 & $0.00^{\mathrm{a}}, 0.86$ \\
\hline
\end{tabular}

${ }^{a}$ Quantity lower than limits of standard curve.

The LaMotte kits always reported the correct value within a given range (data not shown). The biological sensors reported 95\% calibration intervals that included known phosphate concentrations $\leq 7.04 \mathrm{ppm}$, and ammonia concentrations $\leq 1.01 \mathrm{ppm}$. Known nutrient concentrations greater than these values (10.56 and $15.83 \mathrm{ppm}$ phosphate and $1.52 \mathrm{ppm}$ ammonia) were close to, but not within, the $95 \%$ calibration intervals.

To compare the reported nutrient concentration intervals of the biological sensor to commercial kits, each water sample was tested using both the LaMotte phosphate and ammonia-nitrogen test kits, typical of kits used by small farmers in the Chesapeake area (Tables 5 and 6). The commercial kit reported phosphate concentrations in water samples of $\leq 1 \mathrm{ppm}$. Most of the phosphate concentrations reported by the biological sensor included values above $1 \mathrm{ppm}$ and below $10 \mathrm{ppm}$. Notable exceptions included the Crum Creek, Naaman's Creek in Delaware, and the Atlantic shore in Virginia-as well as several samples collected in Maine-which all reported calibration intervals above 10 ppm phosphate. The ammonia commercial kit reported fairly comparable ammonia concentrations to the biological sensor. Thirteen samples were tested by both the kit and the ammonia biosensor; seven of these samples tested by the ammonia-nitrogen kit reported ammonia concentrations within the $95 \%$ confidence interval of the biological sensor. The other six samples were assigned kit nutrient concentrations lower than those ppm values reported by the ammonia biosensor.

Table 4. Comparison of Calculated Ammonia Concentrations to KnOwn Concentrations of Ammonia in Water

\begin{tabular}{lc}
\hline Determined $\left[\mathrm{NH}_{3}\right](\mathrm{ppm})$ & $\begin{array}{c}\text { 95\% Confidence } \\
\text { interval (ppm) }\end{array}$ \\
\hline 1.52 & $1.32,20.2$ \\
1.01 & $0.92,1.31$ \\
0.68 & $0.59,0.96$ \\
0.45 & $0.36,0.73$ \\
0.30 & $0.16^{\mathrm{a}}, 0.52$ \\
0.20 & $0.044^{\mathrm{a}}, 0.39$ \\
\hline
\end{tabular}

${ }^{\mathrm{a}}$ Value extrapolated from standard curve.
Single-copy integrants of $p h o A^{\prime}:: \operatorname{luxCDABE}$ and $g \ln A p 2^{\prime}:: \operatorname{lu} x C D A B E$ into the lacZ site of the E. coli chromosome did not differ from the multicopy plasmid versions in the range or regulation of their response. The only distinction was that the amount of light at all time points was proportionately lower than in the plasmid-borne counterparts (data not shown.) Finally, once each month for a period of 24 months, viability tests of frozen stock cells confirmed that the cells were viable ( $>90 \%$ viability as compared to freshly cultured) and suitable for testing (data not shown).

\section{Discussion}

We have described bioengineered $E$. coli strains carrying plasmid-borne pho $A^{\prime}:: \operatorname{lux} C D A B E$ or $g \ln A p 2^{\prime}:: \operatorname{lu} x C D A B E$ promoter-reporter fusions. These fusions respond to increasing phosphate or ammonia starvation, respectively, by producing a proportionate, quantifiable amount of light via the lux operon. Further, the response is controlled by the respective regulatory systems sensitive to phosphate: phoB (Wanner, 1987) or ammonia: glnFG (Magasanik and Neidhardt, 1987; Reitzer and Magasanik, 1987) limitation. Some investigators have used nitrogen and phosphatesensitive lux $A B$ reporters in P. fluorescens (Kragelund et al., 1995; Jensen et al., 1998), but this required exogenous substrate addition (fatty aldehydes) and does not have the benefit of reflecting the redox or fatty acid pools. In addition, the use of an E. coli host system allowed the testing of the physiological basis of the responses due to the availability of well-characterized mutants in the phosphate- and ammoniaresponsive regulons.

The biological sensors report known concentrations of nutrients with comparable sensitivity to commercial kits. In addition, the viability of long-term storage of frozen, stationary-phase cells used in these measurements was measured. Whether the $p h o A$ and $g \ln A p 2$ promoter::lux fusions were on multicopy plasmids or in chromosomal integrations did not affect their utility. Ideally, specific light units (RLU/OD at $600 \mathrm{~nm}$ ) would have indicated that the light produced by the reporter strains was normalized for growth. Due to instrumentation limitations, those data were not able to be measured simultaneously, However OD readings made at the beginning, middle, and end of each experiment-as well as actually serial dilutions and plating for viabilityindicated that cells had grown steadily during the experiment (data not shown).

\section{Dependence of fusion function on appropriate global regulatory circuitry}

Bioluminescence is a complicated readout integrating alterations of gene expression with the physiological status of the cell since light production depends upon the intercellular energy and redox states. The bioluminescent alterations as a function of nutritional supply documented above suggested that the biosensors were specific indicators of transcription. This hypothesis was supported by the analyses of fusion function in isogenic strains defective in global regulatory circuitry. Phosphate-limited induction of pho $A^{\prime}:: l u x C D A B E$ expression depended upon phoB function, while ammonialimited induction of $g \ln A p 2^{\prime}:: \operatorname{lu} x C D A B E$ was dependent upon $g \ln F$ and $g \ln G$ function. Interestingly, peak height does 
Table 5. Phosphate and Ammonia Concentrations in Chesapeake Water Samples, Within 95\% Confidence Intervals, and Compared to LaMotte Kit

\begin{tabular}{|c|c|c|c|c|c|}
\hline & & \multicolumn{2}{|c|}{ Environmental biosensor } & \multicolumn{2}{|c|}{ LaMotte VM-12 kit } \\
\hline & & {$\left[\mathrm{PO}_{4}\right](p p m)$} & {$\left[\mathrm{NH}_{3}\right](p p m)$} & {$\left[\mathrm{PO}_{4}\right](p p m)$} & {$\left[\mathrm{NH}_{3}\right](\mathrm{ppm})$} \\
\hline Southeastern & Crum Creek & $0.00^{\mathrm{a}}, 2.43$ & $0.47,1.01$ & $<1$ & 0.1 \\
\hline Pennsylvania & Swarthmore well (A4) & $16.67,20.62$ & $0.92,1.54$ & $<1$ & $<0.1$ \\
\hline Delaware River & Naamans C. & $11.80,14.67$ & $0.00^{a}, 0.46$ & $<1$ & $<0.1$ \\
\hline Chesapeake Bay & Choptank R. (Easton) (C1) & $5.63,9.52$ & $0.00^{\mathrm{a}}, 0.14$ & $<1$ & $<0.1$ \\
\hline \multirow[t]{9}{*}{ Watershed (Maryland) } & Choptank R. (Cambridge) (C2) & $3.12^{\mathrm{b}}, 6.95$ & $0.00^{\mathrm{a}}, 0.19$ & $<1$ & $<0.1$ \\
\hline & Nanticoke R. (C3) & $4.11^{\mathrm{b}}, 7.96$ & $0.00^{\mathrm{a}}, 0.20$ & $<1$ & 0.1 \\
\hline & Wicomico R. (C4) & $2.85^{\mathrm{b}}, 6.68$ & $0.00^{\mathrm{a}}, 0.21$ & $<1$ & $<0.1$ \\
\hline & Aberdeen (A1) & $4.54,7.92$ & $0.06^{\mathrm{b}}, 0.64$ & $<1$ & $<0.1$ \\
\hline & Salisbury (A3) & $5.42,8.85$ & $0.00^{\mathrm{a}}, 0.12^{\mathrm{b}}$ & NT & 0.1 \\
\hline & Spa Creek/Severn R. (A5) & $5.00,8.40$ & $0.00^{\mathrm{a}}, 0.36$ & NT & NT \\
\hline & Potomac R./Leonardtown (A6) & $6.12,9.57$ & $0.28^{\mathrm{b}}, 0.86$ & NT & NT \\
\hline & St. Mary's (A7) & $5.60,9.03$ & $0.23^{\mathrm{b}}, 0.82$ & NT & NT \\
\hline & Patuxent R. (A8) & $4.48,7.86$ & $0.23^{\mathrm{b}}, 0.81$ & NT & NT \\
\hline Atlantic shore (Virginia) & (A2) & $16.54,20.47$ & $0.74,1.35$ & NT & NT \\
\hline
\end{tabular}

${ }^{\mathrm{a}}$ Quantity lower than limits of standard curve.

${ }^{b}$ Value extrapolated from standard curve.

NT, not tested.

not correlate with the severity of starvation. This may signify that the cell is metabolically compromised. Since expression of the lux reporter is dependent on robust intermediary metabolism (supplying the necessary fatty acids and reduced flavin mononucleotide and oxygen), growth limitations can lead to diminished light output (Vollmer and Van Dyk, 2004).

Table 2 shows the relative lag times for induction of the phoA response from exponentially growing cells. In addition, a comparison of RLU reported in Table 2 contrasts with those shown in Figure 1A and B by an order of magnitude. While the linear dynamic range of luminometers is between 7 and 9 orders of magnitude, we wished to minimize the variations due to stochasticity and the actually time of harvest during exponential growth. Hence, the use of frozen, single-use aliquots of stationary phase cells was adopted.

\section{Kinetic and standard curves}

Based on previous work with the $p h o A^{\prime}:: \operatorname{lux}$ and $g \ln A^{\prime}:: \operatorname{lux}$ strains (Smulski et al., 1994, 1996), these biosensors were expected to respond to increasing nutrient starvation with proportionate, increasing amounts of light. It was also expected that the light values from the kinetic curves could be taken at one time point, from all nutrient concentrations, and graphed as a function of nutrient concentration, again based on preliminary studies (C. Woodrell, pers. comm.). As expected, the kinetic curves show the dose-dependent response of pho $A^{\prime}:: l u x$ to phosphate limitation, and $g \ln A^{\prime}:: \operatorname{lux}$ to ammonia limitation, over time, and the standard curves show bioluminescence as an inverse function of nutrient concentration. By creating standard curves we are able to quantify previously unknown phosphate and ammonia concentrations in water samples within a $95 \%$ confidence interval of values.

However, although the biosensors responded to nutrient starvation as expected, the standard curves showed that reliability appeared to be limited to the linear portion of the graph, and thus a given range of values, usually between 1 and $24 \mathrm{ppm}$ phosphate, and 0.6 and $1.6 \mathrm{ppm}$ ammonia. At phosphate concentrations lower than $1 \mathrm{ppm}$, it appeared that

Table 6. Phosphate and Ammonia Concentrations in Maine Water Samples, Within 95\% Confidence Intervals, and Compared to LaMotte Kit

\begin{tabular}{|c|c|c|c|c|c|}
\hline & & \multicolumn{2}{|c|}{ Environmental biosensor } & \multicolumn{2}{|c|}{ LaMotte VM-12 kit } \\
\hline & & {$\left[\mathrm{PO}_{4}\right](p p m)$} & {$\left[\mathrm{NH}_{3}\right](p p m)$} & {$\left[\mathrm{PO}_{4}\right](p p m)$} & {$\left[\mathrm{NH}_{3}\right](p p m)$} \\
\hline \multirow[t]{7}{*}{ Southern Maine } & 1706 Rt. 129 (M1) & $1.30,3.61$ & $0.30^{\mathrm{a}}, 0.83$ & $<1$ & $0.1-0.25$ \\
\hline & Pemaquid (M2) & $0.00^{\mathrm{b}}, 0.60$ & NA & $<1$ & $0.1-0.25$ \\
\hline & Stream by lab (M3) & $1.98,4.35$ & NA & $<1$ & $<0.1$ \\
\hline & Cemetary Pond Rt. 129 (M4) & $1.55,3.89$ & $0.11^{\mathrm{a}}, 0.63$ & $<1$ & $<0.1$ \\
\hline & Clarks Love Rd. (M5) & $4.05,6.58$ & $0.00^{b^{\prime}}, 0.00^{\mathrm{b}}$ & $<1$ & $<0.1$ \\
\hline & Parking Lot (M6) & $1.21,3.51$ & $0.79,1.33$ & $<1$ & $<0.1$ \\
\hline & Musk Ln. (M7) & $5.57,8.23$ & $0.22^{\mathrm{a}}, 0.75$ & 1 & 0.1 \\
\hline
\end{tabular}

${ }^{a}$ Value extrapolated from standard curve.

${ }^{\mathrm{b}}$ Quantity lower than limits of standard curve.

NA, not available for testing. 
sometimes the nutrient levels were too low to sustain a linear bacterial stress response. The bacteria were most likely so severely starved for nutrients that they were no longer producing proportionate amounts of light. When limited for nutrients beyond a certain point, the bacteria divert resources such as ATP and $\mathrm{O}_{2}$ to carry out basic metabolic processes; thus, the reporter ceases to be reliable since the lux pathway requires ATP and $\mathrm{O}_{2}$. At high phosphate levels, usually above $24 \mathrm{ppm}$, the bacteria were no longer starved for phosphate, and thus produced very low amounts of light (Fig. 1A and Table 2). The same pattern is seen with the ammonia biosensor (Fig. 3A). That the time of induction varies inversely with the inorganic nutrient concentration may suggest that growth occurs, depleting the nutrient.

Since calibration intervals could only be calculated from the linear portion of the standard curve, the biosensor was not able to accurately report phosphate and ammonia concentrations in any water sample that contained very low levels of these nutrients. In the future, if one were able to fit the entire standard curve, not just the linear portion, with an equation of best-fit, perhaps smaller amounts of nutrients could be accurately reported. However, for the purposes of this study, high nutrient levels are of primary ecological concern since nutrient overenrichment can lead to algal blooms, oxygen depletion, fish kills, and other environmental and health hazards (Burkholder and Glasgow, 1997; Mallin, 2000). Water samples with high nutrient values, past the linear portion of the curve, are possible to test for nutrient concentration since dilutions of each water sample will lead to a nutrient level that falls within the linear portion of the standard curve.

\section{Comparison between biological sensors and commercial kits}

In addition to expecting the biological sensors to respond to nutrient deprivation in a dose-dependent fashion, it was also expected that the biosensors would be of comparable sensitivity, and accuracy, to commercial kits. Since the promoter-lux system uses real-time in vivo analysis of gene expression, there is no need to add exogenous substrates or to lyse the cells. Thus, the biosensors should be able to report small, accurate amounts of nutrients in water samples of comparable concentrations to commercial nutrient kits. In general, the LaMotte phosphate test kit reported smaller phosphate concentrations $(<1 \mathrm{ppm})$ than the biological sensor (most values were between 1 and $10 \mathrm{ppm}$ ) for the water samples collected and tested. Since both the phosphate and ammonia commercial kits, as well as the biological sensors, generally responded to known nutrient concentrations within either the kit's range of values or the biosensors' $95 \%$ confidence intervals, the difference in the phosphate concentrations of collected water samples reported by the two systems cannot be attributed simply to erroneous values determined by the kit and or the biosensors.

Instead, the phosphate biosensor may be reporting higher nutrient levels in the water than the commercial kit due to its ability to detect readily bioavailable nutrient load. We note that more recalcitrant sources of nutrients that are not liberated by $E$. coli enzymes during the incubation will not be measured by our system; however, pretreatment of the water samples with sonication, heating to $50^{\circ} \mathrm{C}$ for $30 \mathrm{~min}$, or agitation overnight $(350 \mathrm{rpm})$ at room temperature did not liberate any apparent sources of relevant nutrients (data not shown). The biosensor should be able to access all phosphate sources, organic and inorganic, in water, because it is a biological system that utilizes alkaline phosphatase and other proteins to access a range of phosphate and nitrogen sources, while the commercial kit tests only for orthophosphates. A test of mixtures containing both inorganic and organic sources of phosphate, in known concentrations, reported accurate concentrations of nutrients in both organic and inorganic phosphate water sources, but the commercial kit reported lower amounts of nutrients for the organic phosphate samples (data not shown).

There were also several water samples that reported significantly higher phosphate nutrient values via the biosensor (from 11.80 to $20.62 \mathrm{ppm}$ ) than the commercial LaMotte kits $(<1 \mathrm{ppm})$. These water sources are all in areas of possibly higher nutrient concentration: wildlife habitats, as well as sources of agricultural and residential fertilizer runoff. Thus, it is possible that most of these phosphate sources are organic, and therefore not detectable by the LaMotte kit.

The ammonia commercial kit also reported fairly low concentrations of ammonia in the water samples tested, and the biosensor reported somewhat comparable ammonia concentrations. Seven samples tested by the commercial kit reported ammonia concentrations within the calibration intervals of the biosensor, and six samples reported lower ammonia values than the biological sensor. As with the water samples that reported higher phosphate concentrations, it is possible that there are some amine-containing compounds that are not reported by the commercial kit (which tests for nonionized ammonia), and thus a lower total ammonia concentration is reported. For example, the bacteria could hydrolyze organic amines that the commercial kit would not recognize and report.

These kits were chosen for the ease of use, sensitivity range, and familiarity to regional farmers. Other more sensitive and sophisticated methods may be used to determine nutrient concentration, but one aim of this study was to determine if engineered bacteria and their light output could be a simple alternative for the colorimetric analysis.

\section{Evaluation of nutrient concentrations reported in the Chesapeake Bay area and in Maine}

Typical phosphate levels in water systems range from 0.005 to $0.150 \mathrm{ppm}$, and ammonia from 0.01 to $0.30 \mathrm{ppm}$, while ammonia toxicity to marine organisms is usually seen at $40 \mathrm{ppm}$ and above (Mallin, 2000). From an environmental health and safety perspective, it was interpreted as a positive sign that the commercial kits reported low nutrient concentrations ( $<1$ ppm phosphate and $<0.25 \mathrm{ppm}$ ammonia) in the Chesapeake Bay area and Maine samples. Due to policy initiatives by federal, state, and other agencies, nitrogen and phosphorus concentrations have decreased significantly from the mid-1980s through 1998 in some of the rivers leading to the Chesapeake. Belval and Sprague (1999) report ammonia concentrations of $<7 \mathrm{ppm}$ and phosphate concentrations of $<1 \mathrm{ppm}$ in the Bay and its tributaries for 1999. Both commercial kits corroborate these findings, as does the ammonia biosensor. 
It would also prove fruitful to test the same sites periodically to account for seasonal and weather variations. A Pfiesteria outbreak occurred in the Chesapeake Bay in August 1997, while the Chesapeake Bay Foundation reports algal blooms from spring to late summer every year (Chesapeake Bay Foundation, 2001). Also, the dead zone found in the mid-Atlantic Coast and the Gulf of Mexico forms every spring (Rayl, 2000). Thus, nutrient accumulation could have occurred in the fall, winter, and spring seasons. It would be worthwhile to collect and test samples at intervals year round, and to monitor fluctuations, including stormwater runoff and stream flow, which can affect nutrient concentrations (Belval and Sprague, 1999). Gillor et al. (2003) measured seasonal fluctuations in total dissolved nitrogen.

\section{Conclusions}

This study reports the construction of bacterial strains for the testing of readily bioavailable phosphate and ammonia levels in freshwater samples. We believe that these strains report levels of these nutrients that are physiologically pertinent, since the transcriptional activation is governed by relevant regulators, thus providing a more accurate report of biologically meaningful phosphate and ammonia. Further, we report a protocol for storage and use of bacteria as reliable reagents, which allow the phosphate and ammonia biological sensors in E. coli to report comparable nutrient loads in water systems as phosphate and ammonia analytical chemistry kits. Improving nutrient testing methods can only add to the growing database of environmental monitoring and research for nutrient overenrichment. Periodic monitoring and management will help to reduce and hopefully prevent problematic phosphate and ammonia overenrichment. This environmental monitoring should include an assessment of all possible bioavailable nutrient sources.

\section{Acknowledgments}

The authors acknowledge the assistance of G. Kannapel and the Microbiology Research Team at Swarthmore College for their support of and contributions to this project. The authors thank M. Bailey (DuPont) for providing oligonucleotides and S. Belkin for advice and comments during the course of this work. The authors would also like to thank P. Everson for assistance with statistics, A. McGarity for discussions about water sample collection and testing, and C. Woodrell for reflections on his group's preliminary results. Those who provided strains used in this study are hereby acknowledged and are listed in Table 1. The authors also gratefully acknowledge those who helped in water sample collection: Leonardo and Flor Cardemil in the Chesapeake collection. Funding for this project was supplied by the American Society for Microbiology (C.V.C.) and the Howard Hughes Medical Institute to Swarthmore College.

\section{Disclosure Statement}

No competing financial interests exist.

\section{References}

Bachmann, B.J. (1996). Derivations and genotypes of some mutant derivatives of Escherichia coli K-12. In Escherichia coli and Salmonella: Cellular and Molecular Biology. F.C. Neidhardt, R.
Curtiss III, J.L. Ingraham, E.C.C. Lin, K.B. Low, B. Magasanik, W.S. Reznikoff, M. Riley, M. Schaechter, and H.E. Umbarger, eds. (American Society for Microbiology Press, Washington, DC), pp. 2460-2488.

Belkin, S. (2003). Microbial whole-cell sensing systems of environmental pollutants. Curr Opin Microbiol 6, 206-212.

Belkin, S., Smulski, D.R., Dadon, S., Vollmer, A.C., Van Dyk, T.K., and LaRossa, R.A. (1997). A panel of stress-responsive luminous bacteria for toxicity detection. Water Res 31, 3009-3016.

Belkin, S., Smulski, D.R., Vollmer, A.C., Van Dyk, T.K., and LaRossa, R.A. (1996). Oxidative stress detection with Escherichia coli harboring a kat $G^{\prime}:$ lux fusion. Appl Environ Microbiol 62, 2252-2256.

Belkin, S., Vollmer, A.C., Van Dyk, T.K., Reed, T.R., and LaRossa, R.A. (1994). Oxidative and DNA damaging agents induce luminescence in E. coli harboring lux fusions to stress promoters. In Bioluminescence and Chemiluminescence: Fundamentals and Applied Aspects. A.K. Campbell, L.J. Kricka, and P.E. Stanley, eds. (John Wiley \& Sons Ltd., Chichester, United Kingdom), pp. 509-512.

Belval, D.L., and Sprague, L.A. (1999). Monitoring nutrients in the major rivers draining to Chesapeake Bay. U.S. Geological Survey, Water-Resources Investigations Report, 99-4238 (Washington, D.C.).

Bender, R.A., Janssen, K.A., Resnick, A.D., Blumenberg, M., Foor, F., and Magasanik, B. (1977). Biochemical parameters of glutamine synthetase from Klebsiella aerogenes. J Bacteriol 129, 1001-1009.

Burkholder, J.M., and Glasgow, H.B., Jr. (1997). Pfiesteria piscicida and other Pfiesteria-like dinoflagellates: behavior, impacts, and environmental controls. Limnol Oceanogr 42, 1052-1075.

Casadaban, M.J., and Cohen, S.N. (1979). Lactose genes fused to exogenous promoters in one step using Mu-lac bacteriophage: in vivo probe for transcriptional control sequences. Proc Natl Acad Sci USA 76, 4530-4533.

Casadaban, M.J., and Cohen, S.N. (1980). Analysis of gene control signals by DNA fusion and cloning in Escherichia coli. J Mol Biol 138, 179-207.

Chen, Y.M., Backman, K., and Magasanik, B. (1982). Characterization of a gene, $g \ln L$, the product of which is involved in the regulation of nitrogen utilization in Escherichia coli. J Bacteriol 150, 214-220.

Chesapeake Bay Foundation. (2001). State of the Bay Report 2000. Available at www.cbf.org/sotb/2000/, 15 April 2001.

Cooper, S.R., and Brush, G.S. (1991). Long-term history of Chesapeake Bay Anoxia. Science 254, 992-996.

Davis, R.W., Botstein, D., and Roth, J.R. (1980). Advanced Bacterial Genetics (Cold Spring Harbor Laboratory, Cold Spring Harbor, NY).

Engebrecht, J., Simon, M., and Silverman, M. (1984). Measuring gene expression with light. Science 227, 1345-1347.

Elsemore, D.A. (1998). Insertion of promoter region::luxCDABE fusions into the Escherichia coli chromosome. Methods Mol Biol 102, 97-104.

Ernsting, B.R., Atkinson, M.R., Ninfa, A.J., and Matthews, R.G. (1992). Characterization of the regulon controlled by the leucine responsive regulatory protein of Escherichia coli. J Bacteriol 174, 1109-1118.

Gillor, O., Hadas, O., Post, A.F., and Belkin, S. (2002). Phosphorus bioavaiilability monitoring by a bioluminescent cyanobacterial sensor strain. J Phycol 38, 107-115.

Gillor, O., Harush, A., Hadas, O., Post, A.F., and Belkin, S. (2003). A Synechococcus PglnA::luxAB fusion for estimation of nitrogen bioavailability to freshwater cyanobacteria. Appl Environ Microbiol 69, 1465-1474. 
Hanahan, D. (1983). Studies on the transformation of Escherichia coli with plasmids. J Mol Biol 166, 557-580.

Jensen, L.E., Kragelund, L., and Nybroe, O. (1998). Expression of a nitrogen related lux gene fusion in Pseudomonas fluorescens DF57 in pure culture and in soil. FEMS Microbiol Ecol 25, 2332.

Kenyon, C., and Walker, G. (1980). DNA damaging agents stimulate gene expression at specific loci in Escherichia coli. Proc Natl Acad Sci USA 77, 2819-2823.

Kikuchi, Y., Yoda, K., Yamasaki, M., and Tamura, G. (1981). The nucleotide sequence of the promoter and the amino-terminal region of alkaline phosphatase structural gene ( $p h o A)$ of Escherichia coli. Nucleic Acids Res 9, 5671-5678.

Koch, B., Worm, J., Jensen, L.E., Højberg, O., and Nybroe, O. (2001). Carbon limitation induces $\sigma^{\mathrm{s}}$-dependent gene expression in Pseudomonas fluorescens in soil. Appl Environ Microbiol 67, 33633-33370.

Kragelund, L., Christofferson, B., Nybroe, O., and de Bruijn, F.J. (1995). Isolation of lux reporter gene fusions in Pseudomonas fluorescens DF57 inducible by nitrogen and phosphate starvation. FEMS Microbiol Ecol 17, 95-106.

LaPorte, D.C., Thorsness, P.E., and Koshland, Jr., D.E. (1985). Compensatory phosphorylation of isocitrate dehydrogenase. A mechanism for adaptation to the intracellular environment. J Biol Chem 260, 10563-10568.

LaRossa, R.A., Smulski, D.R., and Van Dyk, T.K. (1995). Interaction of lead nitrate and cadmium chloride with Escherichia coli $\mathrm{K}-12$ and Salmonella typhimurium global regulatory mutants. J Ind Microbiol 4, 252-258.

LaRossa, R.A., and Van Dyk, T.K. (2000). Applications of stress responses for environmental monitoring and molecular toxicology. In Bacterial Stress Responses. G. Storz and R. HenggeAronis, eds. (ASM Press, Washington, DC), pp. 453-468.

Macnab, R.M. (1987). Motility and chemotaxis. In Escherichia coli and Salmonella typhimurium: Cellular and Molecular Biology. F.C. Neidhardt, J.L. Ingraham, K.B. Low, B. Magasanik, M. Schaechter, and H.E. Umbarger, eds. (American Society for Microbiology, Washington, DC), pp. 732-759.

Magasanik, B., and Neidhardt, F.C. (1987). Regulation of carbon and nitrogen utilization. In Escherichia coli and Salmonella typhimurium: Cellular and Molecular Biology. F.C. Neidhardt, J.L. Ingraham, K.B. Low, B. Magasanik, M. Schaechter, and H.E. Umbarger, eds. (American Society for Microbiology, Washington, DC), pp. 1318-1325.

Makino, K., Shinagawa, H., Amemura, M., and Nakata, A. (1986). Nucleotide sequence of the phoB gene, the positive regulatory gene for the phosphate regulon of Escherichia coli K12. J Mol Biol 190, 37-44.

Mallin, M.A. (2000). Impacts of industrial animal production on rivers and estuaries. Am Sci 88, 26-37.

Menzel, R. (1989). A microtiter plate-based system for the semiautomated growth and assay of bacterial cells for betagalactosidase activity. Anal Biochem 181, 40-50.

Metcalf, W.W., Steed, P.M., and Wanner, B.L. (1990). Identification of phosphate starvation-inducible genes in Escherichia coli K-12 by DNA sequence analysis of psi::lacZ $(M u d \lambda)$ transcriptional fusions. J Bacteriol 172, 3191-3200.

Miller, J.H. (1992). Additional Systems to Monitor Gene Expression in a Short Course in Bacterial Genetics (Cold Spring Harbor Laboratory Press, Cold Spring Harbor, NY), pp. 63-67.

National Research Council. (2001). Clean Coastal Waters: Understanding and Reducing the Effects of Nutrient Pollution Committee on the Causes and Management of Eutrophication (National Academy Press). Washington, DC.
Neidhardt, F.C. (2000). Proteomic analysis of bacterial stress responses. In Bacterial Stress Responses, G. Storz and R. HenggeAronis, eds. (ASM Press, Washington, D.C.), Chapter 28, pp. 445-452.

Neidhardt, F.C., Ingraham, J.L., and Schaechter, M. (1990). Physiology of the Bacterial Cell. A Molecular Approach (Sinauer Associates, Sunderland, MA).

Nixon, S.W. (1988). Physical energy inputs and the comparative ecology of lake and marine ecosystems. Limnol Oceanogr 33, 1005-1025.

Officer, C.B., Biggs, R.B., Taft, J.L., Cronin, L.E., Tyler, M.A., and Boynton, W.R. (1984). Chesapeake Bay Anoxia: origin, development, and significance. Science 223, 22-27.

Paerl, H.W. (1993). Emerging role of atmospheric nitrogen deposition in coastal eutrophication: biogeochemical and trophic perspectives. Can J Fish Aquat Sci 50, 2254-2269.

Quillardet, P., Husiman, O., D'Ari, R., and Hofnung, M. (1982). SOS chromotest, a direct assay for SOS function in Escherichia coli K12 to measure genotoxicity. Proc Natl Acad Sci USA 79, 5971-5975.

Ramsey, F.L., and Schafer, D.W. (1997). The Statistical Sleuth: A course in Methods of Data Analysis, chapter 7 (Wadsworth Publishing Company, Beverly, MA).

Rayl, A.J.S. (2000). Coastal "Dead Zones" get attention. Scientist 14, 12-13.

Reitzer, L.J., and Magasanik, B. (1987). Ammonia assimilation and the biosynthesis of glutamine, glutamate, aspartate, asparagine, L-alanine and D-alanine. In Escherichia coli and Salmonella: Cellular and Molecular Biology. F.C. Neidhardt, R. Curtiss III, J.L. Ingraham, E.C.C. Lin, K.B. Low, B. Magasanik, W.S. Reznikoff, M. Riley, M. Schaechter, and H.E. Umbarger, eds. (American Society for Microbiology, Washington, DC), pp. 302-320.

Reitzer, L.J., and Magasanik, B. (1985). Expression of $g \ln A$ in Escherichia coli is regulated at tandem promoters. Proc Natl Acad Sci USA 82, 1979-1983.

Richardson, K., and Jørgensen, B.B. (1996). Eutrophication: definition, history and effects. In Eutrophication in a Coastal Marine Ecosystem, B. Barker Jørgensen and K. Richardson, eds. (American Geophysical Union, Washington, D.C.).

Rogowsky, P.M., Close, T.J., Chimera, J.A., Shaw, J.J., and Kado, C.I. (1987). Regulation of the vir genes of Agrobacterium tumefaciens plasmid pTiC58. J Bacteriol 169, 5101-5112.

Smulski, D.R., Van Dyk, T.K., Elsemore, D.A., Purohit, H., Vollmer, A.C., and LaRossa, R.A. (1996). Nutritionally-regulated, luxCDABE-based E. coli sensors. H-148 p 509. In Abstracts of the 96th General Meeting of the American Society for Microbiology (American Society for Microbiology, Washington, DC).

Smulski, D.R., Vollmer, A.C., Van Dyk, T.K., Belkin, S., and LaRossa, R.A. (1994). E. coli promoter-lux fusions responsive to nutritional deprivation. FASEB Fed Proc 8, 310.

Standing, D., Maharg, A.A., and Killham, K. (2003). A tripartite microbial reporter gene system for real-time assays of soil nutrient status. FEMS Microbiol Lett 220, 35-39.

Van Dyk, T.K., Majarian, W.R., Konstantinov, K.B., Young, R., Dhurjati, P., and LaRossa, R.A. (1994). Rapid and sensitive pollutant detection by induction of heat shock-bioluminescent gene fusions. Appl Environ Microbiol 60, 1414-1420.

Van Dyk, T.K., Reed, T.R., Vollmer, A.C., and LaRossa, R.A. (1995a). Synergistic induction of the heat shock response in Escherichia coli by the simultaneous treatment with chemical inducers. J Bacteriol 177, 6001-6004.

Van Dyk, T.K., Smulski, D.R., Reed, T.R., Belkin, S., Vollmer, A.C., and LaRossa, R.A. (1995b). Similar responses to adverse environmental conditions by Escherichia coli strains carrying 
$u s p A^{\prime}:: l u x$ or grpE'::lux genetic fusions. Appl Environ Microbiol 61, 4124-4127.

Vollmer, A.C., Belkin, S., Smulski, D.R., Van Dyk, T.K., and LaRossa, R.A. (1997). Detection of DNA damage by use of Escherichia coli carrying rec $A^{\prime}:: l u x$, uvr $A^{\prime}:: l u x$ or alk $A^{\prime}:: l u x$ reporter plasmids. Appl Environ Microbiol 63, 2566-2571.

Vollmer, A.C., and Van Dyk, T.K. (2004). Stress responsive bacteria: biosensors as environmental monitors. Adv Microb Physiol 49, 131-174.

Wanner, B.L. (1987). Phosphate regulation of gene expression in Echerichia coli. In Escherichia Coli and Salmonella Typhimurium: Cellular and Molecular Biology, Vol. 2, F.C. Neidhardt, J. Ingraham, K.B. Low, B. Magasanik, M. Schaechter, and
H.E. Umbarger, eds. (American Society for Microbiology, Washington D.C.), pp. 1326-1333.

Address correspondence to: Amy Cheng Vollmer, Ph.D. Department of Biology Swarthmore College Swarthmore, PA 19081

E-mail: avollme1@swarthmore.edu

Received for publication October 29, 2009; received in revised form March 26, 2010; accepted March 26, 2010. 


\section{Appendix}

\section{Calibration Interval Calculation}

When it is desired to predict an $X$-value that produces a specific response, $Y$, inverse prediction, or calibration, is invoked. In this case, we wanted to predict nutrient concentrations $(X)$ that produce a specific log RLU value $(Y)$. Calibration, or $95 \%$ confidence intervals, was calculated as follows.

Pred $\left\{X / Y_{0}\right\}=\left(Y_{0}-B_{0}\right) / B_{1}$

From standard curve, $y=4.745-0.018354 x$

\begin{tabular}{cccccc}
\hline & $\begin{array}{c}\mathrm{y}^{\wedge} \text { (plug } \\
\mathrm{x} \text {-value } \\
\text { standard } \\
\text { curve) }\end{array}$ & $\begin{array}{c}\mathrm{y} \text { (from } \\
\text { standard } \\
\text { curve) }\end{array}$ & $\begin{array}{c}\text { Upper } \\
\text { into standard } \\
\text { curve) }\end{array}$ & $\begin{array}{c}\text { Lower } \\
\text { calibration } \\
\text { limits }\end{array}$ & $\begin{array}{c}\text { calibration } \\
\text { limits }\end{array}$ \\
\hline 1 & 15.20 & 4.45 & 4.466 & 4.547 & 4.385 \\
2 & 10.13 & 4.58 & 4.559 & 4.628 & 4.489 \\
3 & 6.76 & 4.62 & 4.621 & 4.688 & 4.554 \\
4 & 4.5 & 4.66 & 4.662 & 4.731 & 4.594 \\
5 & 3.00 & 4.68 & 4.689 & 4.760 & 4.619 \\
6 & 2.00 & 4.71 & 4.659 & 4.781 & 4.636 \\
\hline
\end{tabular}

$$
\begin{aligned}
n & =6 \\
x & =6.932 \text { (mean of all } x \text {-values) } \\
s_{\mathrm{x}}{ }^{2} & =24.86 \text { (sample variance of all } x \text {-values) }
\end{aligned}
$$

$$
\begin{aligned}
& \sigma^{2}=8.46 \times 10^{-4} \\
& \begin{aligned}
t^{*}= & -2 \text { for } p<0.05=2.132
\end{aligned} \\
& \begin{aligned}
\text { For } n & =1, \operatorname{SE}\left(\sigma / x_{0}\right)^{2}=\sigma^{2}\left(1 / \mathrm{n}+\left[\left(x_{0}-x\right)^{2} /\left([n-1]^{*} s_{x}{ }^{2}\right)\right]\right) \\
& =(0.000846)\left(1 / 6+\left[(15.20-6.93)^{2} /([6-1][24.86])\right]\right) \\
& =6.065 \times 10^{-4}
\end{aligned}
\end{aligned}
$$

and $\mathrm{SE}\left[\right.$ pred $\left.\left\{X / Y_{0}\right\}\right]=$ square $\operatorname{root}\left(\sigma^{2}+\mathrm{SE}_{\mathrm{u}}{ }^{2}\right)$

$=$ square root $\left(8.46 \times 10^{-4}+6.065 \times 10^{-4}\right)$

$=0.0381$

Upper limit: $y+t^{*}(\mathrm{SE}$ pred $)=4.466+2.132(0.0381)=4.547$

Lower limit: $y-t^{*}(\mathrm{SE}$ pred $)=4.466-2.132(0.0381)=4.385$

This calculation is repeated for each $x$-value in the data set; the new points are plotted together with the original standard curve, and fit to a line as calibration intervals. For more details, see Ramsey and Schafer (1997).

Once calibration intervals are calculated, these equations for these two new lines can be used to determine a range of nutrient concentrations in a given water sample. The $\log$ RLU value of a water sample is plugged into both the lower and upper limit equations, and the resulting values are reported as a calibration interval. RLU, relative light units. 
